\title{
Using The DuPont Decomposing Process To Create A Marketing Model
}

Ted Mitchell, University of Nevada-Reno, USA

Shawn Mitchell, University of Nevada-Reno, USA

Cyndi Cai, University of Nevada-Reno, USA

\begin{abstract}
The DuPont Model of Business is almost 100 years old. It provides a classic template for the decomposition process that can be used to build integrated systems of performance metrics. The marketing field has never embraced the DuPont Model as completely as accounting and finance because the focus is on the earning being return to the owner's equity. Earnings flow is not the same as cash flow and marketing managers are more focused on operating profits than net profits. However, the decomposition process that is used to create the DuPont Model can be applied to the process of creating a Marketing Model. The paper reviews the classic decomposition process and uses it to create a new Marketing Model of Profitability.
\end{abstract}

Keywords: Dupont; Return on Marketing Investment; MROI; ROMI; Return on Sales; ROS; Marketing Model

\section{INTRODUCTION}

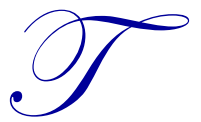

he traditional role that the DuPont formula plays in finance is to help investors select projects and investments that are the most profitable. The first application of the DuPont Model was in 1918. It was used to help with DuPont's decision to become a major stakeholder in General Motors. Over the years, it has evolved into a classic diagnostic tool for identifying strengths, weaknesses and potential improvements to the firm's capital structure in order to maximize shareholder wealth. The application of the DuPont Model for operational marketing decisions is most widely accepted in textbooks dealing with Merchandizing and Retailing (Levy and Weitz, 2007, p. 164). However, the need to have an integrated system of marketing performance measures grows as marketing managers are asked to be more accountable for the profitability of their decisions.

\section{THE DUPONT MODEL AS A SYSTEM OF PERFORMANCE RATIOS}

"The most common mode in which financial statement data are summarized is the ratio form" (Foster, 1986, p. 96). The modern presentation of a DuPont analysis has a focus on an explanation of the differences in two performance rates. In this guise, the primary purpose of the DuPont Model is to help understand why one return on owner's equity, ROE, is superior to another ROE of another investment. The detail in the system of performance ratios that helps explain ROE performance is presented as:

ROE $=$ Net Return on Sales $x$ Asset Turnover Rate x Owner's Leverage

The DuPont System of Performance Ratios is primarily a diagnostic tool. It is popular in modern texts to trace changes in the firm's accounting statements and link them to changes in the ratios in the DuPont System of performance ratios with DuPont Charts. The DuPont Charts can be extremely detailed as individual changes in the accounting statements are traced to their impact on the three different ratios in the DuPont System. Good examples of this charting of accounting into the DuPont Identity are found in Brigham and Ehrhant text (2005, p. 461) and Parrino et.al text (2012, p. 105). However, the DuPont Charts and System of Performance ratios are primarily used for diagnostic purposes and are not examples of the classic decomposition process. "Controlling for the effect of size differences is the most frequently cited motivation for analyzing data in ratio form. The most important assumption underlying the use of ratios, as a control for size differences, is strict proportionality between the numerators and the 
denominators" (Foster, 1986, p. 96). This assumption appears to be honored more in the breach than in practice. The solution for comparing ratios in the absence of strict proportionality is to consider the functional form of the ratio. If the ratio is ROE, then the functional form of ROE is the ROE Business Model.

Net Profit $=$ ROE $x$ the quantity of equity employed.

$\mathrm{NZ}=\mathrm{ROE} \times \mathrm{O}$

With the modern focus on the DuPont System of Performance Ratios as a diagnostic tool, it is easy to forget the original application of the DuPont Model was as a decision tool. The original DuPont model was to help an investor choose between the profitability of two alternative investments.

\section{THE DUPONT MODEL OF BUSINESS}

The role of the DuPont Model of Business is to explain net profits (NZ) in terms of strategic variables, such as the amount of owners' equity employed $(\mathrm{O})$, the amount of total assets employed $(\mathrm{A})$, and the sales revenue generated by the business (R). That is to say, the DuPont Model of Business is used to explain what is causing the difference in the Net Profits of two investments.

Net Profit $=$ Net Return on Sales $\mathrm{x}$ Asset Turnover Rate $\mathrm{x}$ Owner's Leverage $\mathrm{x}$ Equity

NZ = NROS $x$ Turnover Rate $x$ Leverage Ratio $x$ Amount of Equity

$\mathrm{NZ}=$ NROS $\mathrm{x}$ Turnover $\mathrm{x}$ leverage $\mathrm{x} \mathrm{O}$

The original goal was to explain differences in net profit $(\Delta \mathrm{NZ})$ by the differences in return on sales $(\triangle \mathrm{NROS})$, the differences in Asset Turnover ( $\Delta$ Turnover), the differences in Leverage ( $\Delta$ Leverage), and the differences in the amount of Owners' Equity involved $(\Delta \mathrm{O})$.

$\Delta \mathrm{NZ}=\Delta \mathrm{NROS}$ and $\Delta$ Turnover and $\Delta$ Leverage and $\Delta$ Equity

\section{THE STARTING POINT FOR CREATING THE DUPONT BUSINESS MODEL}

The modern focus on the performance ratios as stand-alone metrics for business evaluation and diagnostics makes it easy to forget that every performance ratio or rate of business efficiency is part of a very simple business model. For example, simple business models that explain profit would include:

1) The Return on Assets Model, ROA, Model

Profit $=($ Profit Returned on Assets) $\mathrm{x}$ (the amount of Assets employed $)$

2) The Return on Investment, ROI, Model

Profit $=($ Profit Returned on Inventory) $\mathrm{x}$ (the amount of Inventory on hand)

3) The Return on Business Expenditure, ROBE, Model

Profit $=($ Profit Returned on Business Expenditure $) \times($ the amount Capital Expended $)$

4) The Return on Owner's Equity, ROE, Model

Profit $=($ Profit Returned on Equity $) \times$ (the amount of equity $)$

The simple ROE Model of Business is the starting point for the creation of the DuPont Model. The basic business model using the ROE ratio is illustrated in Figure 1 as the conversion process that generates Net Profit (NZ) from Owner's Equity $(\mathrm{O})$. 


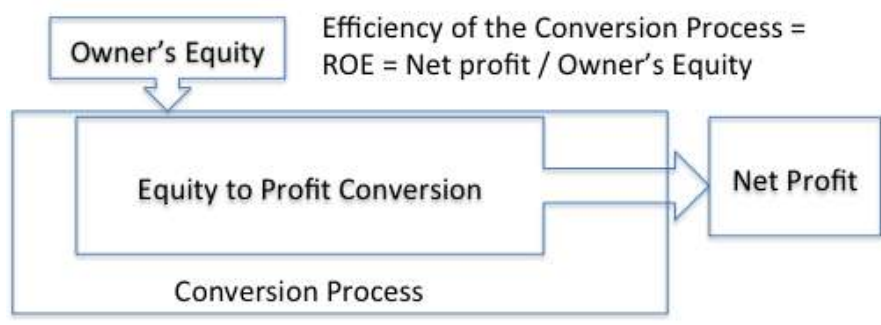

Figure 1: Owners' Equity as Input into Conversion Process which Produces Net Profit

Return on Owner's Equity (ROE) is the ratio of net profit divided by the amount of equity. ROE is easily cast as a measure of the conversion's efficiency in that it is the ratio of an output, profit, over an input, equity.

$\mathrm{ROE}=$ Rate of net profit returned from the amount on equity employed

$\mathrm{ROE}=$ Output $/$ Input $=$ Net Profit $/$ Amount of Equity

$\mathrm{ROE}=\mathrm{NZ} / \mathrm{O}$

The simplest interpretation of the firm's ROE is that a higher rate of profit being returned is a good thing. The simple interpretation of ROE leads many business professionals to assume that a strategy of maximizing ROE must lead to a more profitable business. Robert Parrino et. al. (2012) list and discuss several weaknesses in the application of the "Maximizing ROE" strategy for maximizing the firm's profitability (2012, p. 104).

The simple interpretation 'that a bigger ROE is always better' also leads to the flawed decision model in which the investment opportunity with the highest ROE must be the best investment. The insidious problem with the strategy of always choosing the investment with the highest rate of return is that it can lead to correct decisions as often as it leads to wrong decisions. For example, if Bank A offers a return of $10 \%$ on savings and Bank B offers a return of $20 \%$, then Bank B is the best investment because it will generate the largest amount of profit on the investor's deposit.

However, the strategy of 'choosing the highest ROE' can lead to suboptimal decisions. For example, it is seductive to assume that if the ROE in Firm 1 is $10 \%$ and the ROE in firm 2 is 20\%, then the profit in firm 2 must be higher. However, a look at the operating statements could show that the profit in firm 2 is $\$ 2$ with access to $\$ 10$ in equity and the profit in firm 1 is $\$ 100$ with access to $\$ 1,000$ in equity. The difference in the two profits is being explained more by the disparity in the amount of equity being employed than by the efficiency of the firm's use of the equity.

The mathematics behind the basic ROE Model of Business for explaining the difference in the net profits $(\triangle \mathrm{NZ})$ of two businesses demands that both the efficiency of the business conversion (ROE) and the amount of equity $(\mathrm{O})$ being employed be considered.

The great advantage of the simple ROE business model is that it establishes the protocol in which the difference between the profits of two programs (NZ2 - NZ1) is to be explained by the difference in the amounts of owner's equity being employed $(\mathrm{O} 2-\mathrm{O} 1)$ and the difference in the two rates of efficiency (ROE2 - ROE1). That is to say, the difference in two profits $(\Delta \mathrm{NZ})$ is determined by the impact of the difference in ROE (I $\Delta \mathrm{ROE})$ on the difference in profit and the impact of the difference in the level of equity ( $\mathrm{I} \Delta \mathrm{O})$ on the difference in profit.

$(\mathrm{NZ2}-\mathrm{NZ1})=$ Impact of $(\mathrm{ROE} 2-\mathrm{ROE} 1)+\operatorname{Impact}$ of $(\mathrm{O} 2-\mathrm{O} 1)$

$\Delta \mathrm{NZ}=$ Impact of $\Delta \mathrm{ROE}+$ Impact of $\Delta \mathrm{O}$

$\Delta \mathrm{NZ}=\mathrm{I} \Delta \mathrm{ROE}+\mathrm{I} \Delta \mathrm{O}$ 
The simple ROE Model of Business, in its functional form, allows for the comparison of the $\triangle \mathrm{ROE}$ ratios without meeting the strict assumption of proportionality (Mitchell et. al., 2007).

The creator of the DuPont Model of Business recognized that the basic ROE Model for converting equity into profit was too aggregated to help investors understand enough of the details to make wise investments. He knew that there were many other variables, beyond the level of equity employed, which could impact the efficiency of the conversion process. The ROE ratio could be impacted by the total number of assets, the intangible assets, the current assets, the net sales revenue, the operating sales revenue, the level of productive business expenditures, the nonproductive business expenses, etc. Decomposing the simple ROE Model into a more detailed model of the conversion process was an obvious plan for explaining the differences in the profits of two firms. The brilliance of the DuPont decomposition was to have the destruction of the ROE metric result into three performance ratios that were already meaningful to investors.

\section{THE STEPS IN THE CLASSIC DECOMPOSITION PROCESS}

Before taking the decomposition process to create a Model of Marketing Profitability, we shall review the steps in the classic decomposition process using the DuPont Model as our example. Many textbooks leave the reader with the impression that the DuPont analysis is essentially a matter of substituting a single complex rate of performance for multiple rates of performance. However, decomposition is not a simple matter of substitution. There are two major steps in the process of decomposing a single ratio into multiple ratios. The first step is to reformulate the conversion process in the business model to include the variables currently ignored in the model's description. The inclusion of one or more additional variables in the conversion process leads to a complex and highly aggregated measure of the conversion processes' efficiency. The second step in the decomposition process is to decompose the aggregated performance into its constituent performance measures.

\section{The First Step in Decomposing the Simple ROE Model of Business}

The first step in decomposing the conversion process is to identify which of the many elements play a part in the business conversion process. For our decomposition of the ROE Model into the DuPont, we will assume that the amount of assets (A) and the amount of sales revenue (R) are elements that have serious roles to play in the generation of net profit. The inclusion of the assets and sales revenues to conversion process makes the reformulation of the efficiency rate look more complex and aggregated.

The mathematics of the inclusion process is to ensure that the new variables are included without changing the overall measure of efficiency (ROE). Recognizing the multiplication of ROE by unity changes nothing in the efficiency rate, and that the amount of assets divided by itself is unity, provides the solution to expanding the simple model of the conversion process into an aggregated ratio that includes the variables of net profit, assets, sales revenue, and owner's equity.

$$
\begin{aligned}
& \mathrm{NZ}=(\mathrm{ROE} \times 1 \times 1) \times \mathrm{O} \\
& \mathrm{NZ}=(\mathrm{ROE} \times \mathrm{A} / \mathrm{A} \times \mathrm{R} / \mathrm{R}) \times \mathrm{O} \\
& \mathrm{NZ}=(\mathrm{NZ} / \mathrm{O} \times \mathrm{A} / \mathrm{A} \times \mathrm{R} / \mathrm{R}) \times \mathrm{O} \\
& \mathrm{NZ}=((\mathrm{NZ} \times \mathrm{A} \times \mathrm{R}) /(\mathrm{O} \times \mathrm{A} \times \mathrm{R})) \times \mathrm{O}
\end{aligned}
$$

The efficiency of the conversion process is now measured by the aggregated ratio ((NZ x A x R $) /(\mathrm{O} \times \mathrm{A} \times$ $\mathrm{R})$ ). The aggregated ratio is kept manageable by having the analyst select strategic variables that are important to the decision-maker. The aggregated ratio of the conversion efficiency is the raw formulation of the DuPont Business Model (Figure 2). 


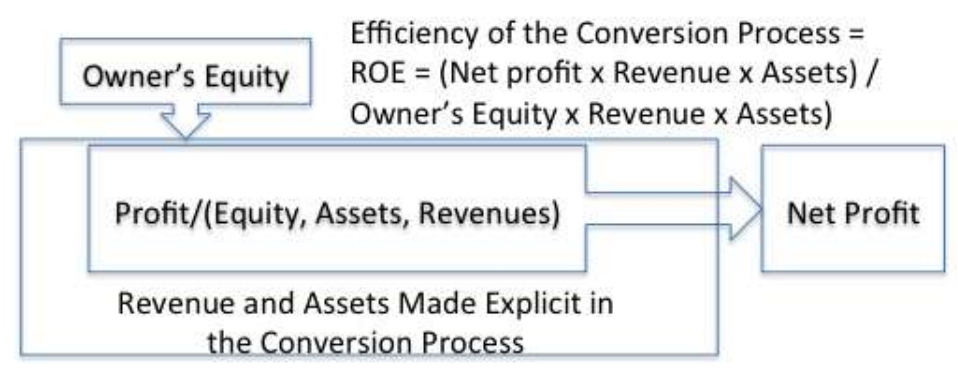

Figure 2: The Raw Version of the DuPont Business Model

\section{Decomposing the Aggregated Efficiency Ratio}

The second step in the creation of the DuPont model of business is the actual decomposition of the aggregate ratio of efficiency. The decomposition process is to reorganize the elements in the numerator and denominator of the aggregated ratio into a system of simpler, less aggregated, ratios. The classic version of the DuPont Business Model was the result of reorganizing the aggregate ratio into three well-known ratios.

$\mathrm{NZ}=(\mathrm{NZ} / \mathrm{R}) \times(\mathrm{R} / \mathrm{A}) \times(\mathrm{A} / \mathrm{O}) \times \mathrm{O}$

Net Profit $=(($ Return on Sales Revenue $) \times($ Asset Turnover Ratio $) \times($ Owners' Leverage $)) \times$ Equity

The DuPont Business Model (Figure 3) predicts that net profits are the result of four strategic variables. The obvious change from the basic ROE Model is that ROE, as the measure conversion efficiency, has been completely replaced by a system of three integrated performance ratios.

ROE $=$ NROS $x$ Turnover Rate $x$ Leverage Ratio

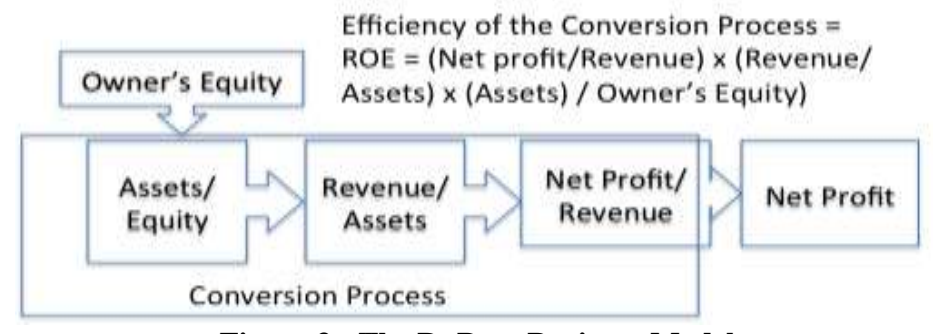

Figure 3: The DuPont Business Model

DuPont profit Business Model provides the basis for an improved decision protocol for choosing between investment opportunities. The difference between the profits from two investments $(\Delta \mathrm{NZ})$ is to be explained by the impact of the differences in:

1. the Net Return on Sales (I $\triangle$ NROS)

2. the Asset Turn Over Rate (I $\Delta$ TR)

3. the leverage rate $(\mathrm{I} \Delta \mathrm{LR})$

4. the difference in the level of equity invested $(\mathrm{I} \Delta \mathrm{O})$

There are mathematical models for calculating the impact of the changes in terms of the net profit dollars. That is to say, if the difference in the net profits is $\$ 20$, the sum of the dollars due to the individual impacts must equal \$20 (Mitchell et. al., 2007).

$\Delta \mathrm{NZ}=\mathrm{I} \Delta \mathrm{NROS}+\mathrm{I} \Delta \mathrm{TR}+\mathrm{I} \Delta \mathrm{LR}+\mathrm{I} \Delta \mathrm{O}$ 
There is no doubt that the investor's appreciation of what makes Firm 1 more profitable than Firm 2 is in the details provided by the impacts of the individual performance changes. A potential investor will judge investments differently when the biggest part of the profit improvement is due to a higher ROS (more efficient operations) than when the biggest part of the difference in the two profits is due to higher leverage on the equity (i.e., more risk).

Farris et al. (2010, p. 372) have identified the strengths in having performance ratios that are part of a performance system. The DuPont Business Model provides the classic example of taking a well-known performance ratio (e.g., ROE) and restructuring it into a performance system for integrated analysis. The potential disadvantage of decomposition is that decomposition may destroy a well-known and understood metric and replace it with multiple ratios that are unknown and less understood. This problem is easily appreciated when a sequential approach is taken to decomposition.

\section{SEQUENTIAL DECOMPOSITION OF THE BASIC ROE MODEL}

However, the aggregation/decomposition of the basic ROE Business Model and the destruction of the ROE ratio need not have been done in a single step as illustrated and demonstrated above. The basic ROE model could have been sequentially decomposed into, first, the Return on Assets and Leverage Model and then, second, to have had the ROA ratio decomposed into the Return on Sales Model. The ROE conversion process is expanded to reflect the total assets in the business model. For example, the basic ROE Model is expended to include total assets (A).

$\mathrm{NZ}=\mathrm{ROE} \times \mathrm{O}$

$\mathrm{NZ}=(\mathrm{NZ} / \mathrm{O}) \times(\mathrm{A} / \mathrm{A}) \times \mathrm{O}$

$\mathrm{NZ}=\{\mathrm{NZ} \times \mathrm{A}) /(\mathrm{O} \times \mathrm{A})\} \times \mathrm{O}$

The aggregated efficiency ratio is decomposed into the ROA rate and the Leverage ratio.

$\mathrm{NZ}=[(\mathrm{NZ} / \mathrm{A}) \times(\mathrm{A} / \mathrm{O})] \times \mathrm{O}$

Net Profit $=($ Return on Assets $) \times($ Owner's Leverage Rate $) \times$ Owners' Equity

The ROA ratio is expanded to have an aggregated efficiency ratio that includes sales revenue (R).

$\mathrm{NZ}=(\mathrm{NZ} / \mathrm{A}) \times(\mathrm{R} / \mathrm{R}) \times$ Leverage $x$ Owner's Equity

$\mathrm{NZ}=[(\mathrm{NZ} \times \mathrm{R}) /(\mathrm{R} \times \mathrm{A})] \times$ Leverage $\times$ Owner's Equity

The aggregated efficiency ratio is decomposed into Return on Sales and Asset Turnover rates.

$\mathrm{NZ}=[(\mathrm{NZ} / \mathrm{R}) \mathrm{x}(\mathrm{R} / \mathrm{A})] \mathrm{x}$ Leverage $\mathrm{x}$ owner's equity

Net Profit $=($ Net Return on Sales) $\mathrm{x}$ (Asset Turnover Ratio $) \times$ Leverage $\mathrm{x}$ Equity

The downside of the decomposition process is that it can destroy a popular and useful performance rate (e.g., ROA). In the DuPont Model, it is fortunate that ROA is replaced by two equally well-known and popular metrics. The art in the decomposition process is to have a system of performance ratios that offers a sufficient improvement in the analysis to warrant the loss of the performance ratio being destroyed.

\section{THE EXPANSION FROM NET PROFIT TO OPERATING PROFIT}

In the century that investors have employed the DuPont Model to help choose between investment opportunities, there has been very little popular advancement in the further decompositions of the classic DuPont 
Model. The one performance ratio in the DuPont Business Model that investors consistently seek to decompose further is the net return on sales revenue (NROS). Investors often seek details on the impact that the firm's taxes and interest payments are having on the reduction of the firm's operating profit - i.e., the profit before interest and taxes (Z) - and the net profit - i.e., the profit available to shareholders after interest payments and taxes (NZ).

The most direct way to decompose the rate of net profit returned on sales, NROS is found at Financial Trading Systems website (2011). The basic net return on sales (NROS) Model structures the business conversion process as one in which sales revenues (R) are being converted into net profits (NZ) and the efficiency of the conversion process is NROS rate.

$\mathrm{NZ}=\mathrm{NROS} \times \mathrm{R}$

The expansion of the NROS Model of Business is expanded to bring earnings before taxes (EBT) and the operating profit (Z) directly into the NROS model.

$\mathrm{NZ}=(\mathrm{NZ} / \mathrm{R}) \times(\mathrm{EBT} / \mathrm{EBT}) \times(\mathrm{Z} / \mathrm{Z}) \times \mathrm{R}$

$\mathrm{NZ}=(\mathrm{NZ} / \mathrm{EBT}) \times(\mathrm{EBT} / \mathrm{Z}) \times(\mathrm{Z} / \mathrm{R}) \times \mathrm{R}$

Net Profit $=($ Tax Burden Rate $) \times$ (Interest Burden Rate $) \times($ Operating Return on Sales Revenue $) \times$ (the amount of sales revenue)

The destruction of the Net Return on Sales (NROS) through decomposition into the Operating Return on Sales (ROS), Tax Burden Rate, and Interest Burden Rate is not found in most business texts. Although the definition and the role of the operating return on sales (ROS) is well known, the other two rates are rather specialized and not widely known.

The alternative to the classic decomposition is direct substitution. An example of direct substitution for the destruction of the Net Return on Sales (NROS) is presented in the CFA exam guide (Investopedia, 2010). The destruction of the NROS ratio occurs with substitution of NZ = EBT (1-tax rate) and the EBT $=\mathrm{Z}-$ interest) in the DuPont Business Model.

$\mathrm{NZ}=$ NROS $\mathrm{x}$ Asset Turnover $\mathrm{x}$ leverage $\mathrm{x}$ equity

$\mathrm{NZ}=(\mathrm{NZ} / \mathrm{R}) \times(\mathrm{R} / \mathrm{A}) \times(\mathrm{A} / \mathrm{O}) \times \mathrm{O}$

Substitute NZ = (Earnings before taxes) $(1-$ tax rate $)$ or NZ $=$ EBT $(1-t)$

$\mathrm{NZ}=(\mathrm{EBT}(1-\mathrm{t}) / \mathrm{R}) \times(\mathrm{R} / \mathrm{A}) \times(\mathrm{A} / \mathrm{O}) \times \mathrm{O}$

$\mathrm{NZ}=(\mathrm{EBT} / \mathrm{R}) \times(\mathrm{R} / \mathrm{A}) \times(\mathrm{A} / \mathrm{O}) \times(1-\mathrm{t}) \times \mathrm{O}$

Substitute EBT $=($ Operating Profit - Interest Expense $)$ or EBT $=(Z-i)$

$\mathrm{NZ}=(\mathrm{Z}-\mathrm{i}) / \mathrm{R} \times(\mathrm{R} / \mathrm{A}) \times(\mathrm{A} / \mathrm{O}) \times(1-\mathrm{t}) \times \mathrm{O}$

$\mathrm{NZ}=(\mathrm{Z} / \mathrm{R}-\mathrm{i} / \mathrm{R}) \times \mathrm{R} / \mathrm{A} \times(\mathrm{A} / \mathrm{O}) \times(1-\mathrm{t}) \times \mathrm{O}$

A partial multiplication results in:

$\mathrm{NZ}=\{[(\mathrm{Z} / \mathrm{R}) \times(\mathrm{R} / \mathrm{A})]-(\mathrm{i} / \mathrm{A})\} \times[(\mathrm{A} / \mathrm{O}) \times(1-\mathrm{t}) \times \mathrm{O}]$ 
where $\mathrm{Z} / \mathrm{R}=$ operating profit returned on sales (ROS)

$\mathrm{R} / \mathrm{A}=$ the asset turnover rate

$\mathrm{i} / \mathrm{A}=$ the interest coverage rate

$\mathrm{A} / \mathrm{O}=$ the owners' leverage ratio

$\mathrm{O}=$ the amount of Owners' Equity employed

The substitution approach to the destruction of the NROS leaves a more complex model than the classical decomposition process and is certainly more difficult to describe to investors.

However, the decomposition of the net return on sales (NROS) into the operating return on Sales (ROS) is the dividing line between decompositions that are of interest to investors choosing among firms as potential investments to those decompositions that are of interest to promotion managers choosing among marketing projects to invest in. Marketing managers are far more interested in models dealing with operating profits than with net profits being made available to investors.

\section{THE BASIC MARKETING MODEL AND MARKETING PERFORMANCE RATES}

In the last few years, marketing measures of performance have been moving from operating measures such as the number of leads generated by advertising, the number of sales generated per call, amount of revenue generated per campaign, etc., to performance measures explaining profits generated by marketing expenditures or investments in marketing programs.

The definition of marketing profit (M) is the amount of contribution left to cover non-marketing expenses after all the marketing expenditures (E) - that were directly employed for creating sales revenue (R) in the period have been subtracted from the gross profit $(\mathrm{G})$. That is to say,

Marketing Profit $=$ Gross Profit - All Direct Marketing Expenditures

$\mathrm{M}=\mathrm{G}-\mathrm{E}$

The amount of marketing profit (M) would be calculated and found on the operating statement between the gross profit $(\mathrm{G})$ and the operating profit $(\mathrm{Z})$. The direct marketing expenditures would normally include items such as advertising, consumer promotions, sales force salaries, packing, packaging, and dealer promotions. The direct marketing expenses would not include indirect expense such as marketing administration, market research and product development. It has become popular for some authors (Best, 2013, p. 53; Lenskold, 2003, p. 19) to refer to marketing expenses (E) as marketing investments. The term marketing 'investment' leads to the definition of the marketing profit to 'investment' ratio as the Marketing Return on Investment (MROI). For our purposes, the term 'investment' is confusing when the analysis deals with marketing assets and misleading when expenses are classified as assets. We shall eschew the term marketing 'investment' and use the term marketing expenses. We define the ratio of marketing profit (M) to marketing expenses (E) as the Return on Marketing Expenditures (ROME).

ROME $=($ Gross Profit - Marketing Expenses $) /$ Marketing Expenses

$\mathrm{ROME}=(\mathrm{G}-\mathrm{E}) / \mathrm{E}$

\section{THE BASIC ROMA MODEL OF MARKETING PROFITABILITY}

The basic model of marketing profitability would be the profit being returned on marketing assets (ROMA). Apart from inventory, square footage of selling space, sales force cars, websites, etc., most of the marketing assets are intangible and don't show up on the balance sheet. For example, assets, such as customer, loyalty, brand equity, product quality, and store location, are very important factors in the creation of sales, but they are not recorded on the balance sheet. However, the marketing profit being return on assets is the starting place when attributing profitability to marketing. 
The basic ROMA model would be:

Marketing Profit $=($ Return on Marketing Assets $) \times$ Assets

$M=$ ROMA $x$ A

In some operations, such as retailing and merchandizing, the practical definition of assets would include inventory categories and selling space. The basic model of marketing profitability could be expanded and decomposed to include a type of Inventory and total marketing assets.

$M=\operatorname{ROMA} \times(I / I) \times A$

$\mathrm{M}=(\mathrm{M} \times \mathrm{I}) /(\mathrm{I} \times \mathrm{A}) \times \mathrm{A}$

$\mathrm{M}=(\mathrm{M} / \mathrm{I}) \times(\mathrm{I} / \mathrm{A}) \times \mathrm{A}$

Marketing Profit $=($ Return on a type of Inventory) $\mathrm{x}$ (ratio of the Inventory to total marketing assets) $\mathrm{x}$ (amount of marketing assets)

\section{EXTENDING AND DECOMPOSING THE ROMA MODEL TO INCLUDE SALES REVENUE}

The most general extension and decomposition to the Basic ROMA Model would be its expansion to include sales revenue (R) and its decomposition to result in the Marketing Return on Sales (MROS) and the Marketing Asset Turnover rate.

$M=\operatorname{ROMA} \times(\mathrm{R} / \mathrm{R}) \times \mathrm{M}$

$M=(M \times R) /(A \times R) \times M$

$M=(M / R) \times(R / A) \times M$

Marketing Profit $=$ MROS x Marketing Asset Turnover x Marketing Assets

With a clear role for the marketing return on sales (MROS) to play in the basic marketing model of profitability, then it becomes the focal point for the next tier of expansion and decomposition.

\section{EXPANDING AND DECOMPOSING THE MARKETING RETURN ON SALES (MROS)}

The basic model of profitability associated with the MROS is expanded with the inclusion of the direct marketing expenditures for the period $(\mathrm{E})$.

Marketing Profit $=$ MROS x (Sales Revenue $)$

$\mathrm{M}=\operatorname{MROS} \times(\mathrm{E} / \mathrm{E}) \times \mathrm{R}$

$\mathrm{M}=(\mathrm{M} \times \mathrm{E}) /(\mathrm{R} \times \mathrm{E}) \times \mathrm{R}$

$M=(M / E) \times(E / R) \times R$

$\mathrm{M}=$ ROME $\mathrm{x}$ Expenditure Rate as a Percentage of Sales $\mathrm{x}$ Sales Revenue

Marketing Profit $=$ Return on Marketing Expenditures $\mathrm{x}$ Percent of Sales x Revenue 
The Return on Marketing Expenditures (ROME) reflects the fundamental model of market effort with the interpretation that greater marketing expenditures should lead to greater profits. The marketing expenditures as a percentage of sales provide the classical check on the rate of spending. The decomposition of the Marketing Return on Sales (MROS) and its destruction into the Return on Marketing Expenditures (ROME), and the marketing expenditure rate based on sales, Percent of Sales, incorporates both new and old measures of performance.

The latest clamor in marketing management is for the Marketing Return on Investment (MROI) to be held as the central metric of marketing management. Many feel that MROI is the metric of profitability to which marketing managers should be held accountable. However, the MROI is, in fact, the same performance metric as the Return on Marketing Expenses (ROME).

The oldest and best-known method for measuring the marketing expense rate is to identify the rate of marketing expenditures as a percentage of sales revenue. Operating statements traditionally report major elements on the operating statement as percentages of revenue. Marketing's Percent of Sales ratio is a classic budgeting and accounting control metric.

However, the feature that is missing in the above model of marketing profitability is the profitability of the sales. Unfortunately, to decompose the Model of Marketing Profitability to include the Gross Return on Sales or Markup results in a shift away from the classic metric of measuring rates of marketing expenditure as percentages of the sales revenue to a new measure of expenditure rate. The new measure of expenditure rate is marketing expenses as a percentage of the gross profit.

\section{DECOMPOSING THE PERCENTAGE RATE OF EXPENDITURE ON SALES}

The MROS Model of Marketing Profitability discussed above is:

Marketing Profit $=$ ROME $x$ Percent of Sales $x$ Sales Revenue

$M=\operatorname{ROME} \times(E / R) \times R$

and it is expanded with the gross profit of the operation $(\mathrm{G})$ :

$M=\operatorname{ROME} \times(\mathrm{E} / \mathrm{R}) \times(\mathrm{G} / \mathrm{G}) \times \mathrm{R}$

$M=\operatorname{ROME} \times(\mathrm{E} / \mathrm{G}) \times(\mathrm{G} / \mathrm{R}) \times \mathrm{R}$

$\mathrm{M}=$ ROME $\mathrm{x}$ (Expenditure rate as Percentage of Gross Profit) $\mathrm{x}$ (Gross Return on Sales) $\mathrm{x}$ Sales Revenue

This decomposition of the classic marketing expenditure rate has the obvious advantage of explicitly bringing to light changes in the markup percentage or gross return on sales as explanations of changes in marketing profits. It has the disadvantage of losing a traditional accounting measure and an easily understood measure of spending.

\section{THE MODEL OF MARKETING PROFITABILITY WITH MARKUP}

The destruction of the traditional percentage of sales metric into markup percentage and expenditures as a rate of gross profit allows for the reinstitution of the MROS as:

Marketing Profit $=$ ROME $\mathrm{x}$ Percent of Gross Rate $\mathrm{x}$ Markup Percent $\mathrm{x}$ Marketing Asset Turnover $\mathrm{x}$ Marketing Assets 


\section{CONCLUSION}

The Basic Model of Marketing Profitability developed in the above paragraphs can be expanded further if the marketing manager needs more details on the profitability of two projects' business units. There is always a trade-off in the decomposition of Business Models between gaining more detail and losing well-known performance metrics. However, the Model, as presented, provides a system of four integrated performance rates that are easy to understand and provide a framework for explaining changes in marketing profit.

\section{AUTHOR INFORMATION}

Ted Mitchell, Ph.D., is a faculty member in Marketing at the College of Business at the University of Nevada, Reno. He has strong research interests in the practical applications of financial rates and marketing rates of return in the accounting for marketing performance. E-mail: Theodorem@unr.edu (Corresponding author)

Shawn P. Mitchell is an award-winning veteran of the Afghanistan Campaign and is a former US Naval Supply Corps officer. He holds a B.S. in International Business from the University of Nevada, Reno, and a M.A. in International Relations from the University of Oklahoma. He has strong research interests in tourist development in emerging economies. E-mail: shawn@ shawnpmitchell.com

Renjie (Cyndi) Cai holds a B.S. in Finance and is a graduate student finishing her Masters in Finance at the University of Nevada, Reno. E-mail: cyndi_cai@yahoo.com

\section{REFERENCES}

1. Best, Roger, (2009), Market Based Management, Fifth Edition, Pearson Education, Inc. Upper Saddle River, NJ.

2. Brigham, E. and M. Ehrhardt (2005) Financial Management: Theory and Practice, $11^{\text {th }}$ Edition, Thompson South Western.

3. CFA Exam Guide, Investopedia. http://www.investopedia.com/exam-guide/cfa-level-1/financialratios/return-equity-dupont-system.asp\#ixzz2LkPxnbs4

4. Davis, John, (2007), Measuring Marketing: 103 Metrics Every Marketer Needs. John Wiley and Sons Pte, Ltd. Singapore.

5. $\quad$ Farris, Paul W., Bendle, N.T., Pfeifer, P.E., Reibstein, D.J. (2006), Marketing Metrics: 50+ Metrics Every Marketing Manager Should Master, Pearson Education, Inc. publishing as Wharton School Publishing, Upper Saddle River, NJ.

6. Foster, George. (1986), Financial Statement Analysis $2^{\text {nd }}$ Edition (Englewood Cliffs, NJ,), Prentice-Hall, Inc.

7. Higgins, Robert. (2004) Analysis for Financial Management, 7th Edition, McGraw-Hill-Irwin.

8. Lenskold, James, D., (2003), Marketing ROI: The Path to Campaign, Customer, and Corporate Profitability, McGraw-Hill, Published as American Marketing Association, New York, NY.

9. Levy, Michael, and Barton Weitz, (2007), Retailing Management, $6^{\text {th }}$ Edition, McGraw-Hill Irwin.

10. Mitchell, T., Jim Stutzman et al. (2007) "Incremental Financial Ratio Analysis: Bridging the Gap Between Comparative Static and Trend Analyses," Journal of Business and Economic Perspectives, Volume XXXIII, July.

11. Parrino, R., D. Kidwell, and T. Bates (2012), Fundamentals of Corporate Finance, $2^{\text {nd }}$ Edition, John Wiley and Sons, Inc

12. Valuation Tutor Software, OS Financial Trading System, 2011. http://www.ftsmodules.com/public/texts/valuationtutor/VTChp2/topic5/topic5.htm 


\section{NOTES}

